\title{
Influence of pH on Ability of High Grade Bentonite to Adsorb Aflatoxin in Broiler Diets
}

\author{
Indresh.H.C, ${ }^{1}$ Devegowda.G, ${ }^{2}$ S. Wilfred Ruban ${ }^{3,}$ M.C. Shivakumar ${ }^{4}$ \\ ${ }^{I}$ Dept. of Livestock Production and Management, Veterinary College, Hassan, Karnataka \\ ${ }^{2}$ Former Professor \& Head,Division of Animal Science, Veterinary College, Hebbal, Bangalore; \\ ${ }^{3}$ Assistant Professor, Department of Livestock Products Technology, Veterinary College, Hassan, Karnataka.; \\ ${ }^{4}$ Professor, Dept. of Livestock Production and Management, Veterinary College, Hassan, Karnataka.
}

\begin{abstract}
In Vitro trial was conducted to evaluate the binding ability of commercial high grade bentonite $(H G B)$, on aflatoxin $(A F)$ in broiler diets at $\mathrm{pH} 4.5$ and 6.5. Contaminated substrate containing $A F$ was added to broilers chicken diets to get the desired level of $0.5 \mathrm{ppm}$. A high grade bentonite was added at 0.5, 0.75 and 1.0 per cent levels to the contaminated diet and incubated for three hours. At $4.5 \mathrm{pH}, 84.90,88.47$ and $92.90 \mathrm{per}$ cent binding of $A F$ was recorded at 0.5, 0.75 and 1.0 per cent inclusion levels of $H G B$ respectively $(P<0.05)$. At $6.5 \mathrm{pH}, 87.60,91.47$ and 96.80 per cent binding of $A F$ was recorded at 0.5, 0.75 and 1.0 per cent inclusion levels of $H G B$ respectively $(P<0.05)$. In the present trial it was evident that both at $p H 4.5$ and 6.5 the binding ability of HGB at the inclusion level of one percent was significantly higher.
\end{abstract}

Key words: Aflatoxin, High grade bentonite, $\mathrm{pH}$, In Vitro binding.

\section{INTRODUCTION}

In order to support and sustain the massive spurt in poultry production in India, there is a great need of the quality feed that is ideal not only in terms of the nutrient composition, but also free from harmful and toxic principles. The need of the quality input is very much felt in any fast growing industry [1].

The susceptibility of feed ingredients and compounded feeds by virtue of their moisture content has led to the growth of fungus leading to the elaboration of the secondary metabolites referred to as 'Mycotoxins'. The fungal contamination of feedstuffs occurs at various stages of production, harvesting, handling, processing and storage [2]. Among different known Mycotoxins, aflatoxin, ochratoxin and T-2 toxins are of major concern to poultry, livestock and humans. Co-contamination of feedstuffs with multiple mycotoxins is a common scenario [3].

Among aflatoxin $(\mathrm{AF}), \mathrm{AFB}_{1}$ are highly toxic and carcinogenic fungal secondary metabolites produced by $A$. flavus, A. parasiticus and Penicillium puberculum. Aflatoxin ingestion leads to aflatoxicosis, which is a chronic or acute condition characterized by growth reduction, bruising, decreased feed consumption and feed conversion efficiency, immunosuppression and mortality. The major adverse effects of aflatoxin lie in its residual toxic effect in food products [4].

At present, one of the more encouraging approaches to make the feed harmless is the addition of nonnutritive and natural adsorbent materials to the contaminated feed in order to selectively bind the mycotoxin during the digestive process. The major advantages of these adsorbents include low cost, safety, and the ease of addition to animal feed. Layered amino silicates, such as sodium bentonite, have been found effective in counteracting Mycotoxins [5]. High Grade Bentonite (HGB), a natural raw material produced from purification and filtration of crude bentonite is claimed to posses' high adsorption capacity due to high surface area $[5,6]$. However, ability of bentonite to bind mycotoxins depends on $\mathrm{pH}$, molecular arrangements and its geographic region of origin [7]. In view of the above, the present experiments were planned to evaluate the efficacy of HGB (High grade bentonite) to adsorb aflatoxin in feed at different $\mathrm{pH}$.

\section{MATERIAL AND METHODS}

The binding efficacy of high grade bentonite (HGB) was evaluated in AF contaminated feed under simulated in situ gastrointestinal tract of chicken.

2.1 Experimental design: The toxin level studied was 0.5-ppm aflatoxin and it was tested with and without the addition of the $0.5,0.75$ and 1.00 per cent level of binding agent, high -grade bentonite (HGB). Thus, a total of 4 treatments were employed (Table 1 and 2). Further, each of these treatments was tested at two pH levels of 4.5 and 6.5 so as to postulate the aflatoxin adsorption binding efficacy of high-grade bentonite in the fore and mid portions of the GI tract of chicken. Each of these treatments was evaluated on triplicate samples. 
2.2 Production and quantification of aflatoxin: Aflatoxin was produced on rice using pure culture of Aspergillus parasiticus MTCC 1894* similar to the method described by Shotwell et al., [7] Aflatoxin was extracted as per Romer [8] and was quantified by TLC as outlined in AOAC [9].

2.3 Experimental procedure: Twenty five grams compound broiler starter feed was taken in a $250 \mathrm{ml}$ Erlenmeyer flask. To this, 0.5 -ppm aflatoxin was added to feed. To the treated flasks, high-grade bentonite was added at $0.5,0.75$ and 1.00 per cent level while the feed in the control flask was left untreated. One hundred $\mathrm{ml}$ citric acid-sodium phosphate buffer of the desired $\mathrm{pH}$ (either 4.5 or 6.5 ) was added to each flask. Contents of the flask were thoroughly mixed for $30 \mathrm{~min}$ on a horizontal shaker to ensure proper contact of the binder with the aflatoxin. The flasks were incubated at $37{ }^{\circ} \mathrm{C}$ for three hrs in an incubator. The contents were filtered and the residue was dried at $37^{\circ} \mathrm{C}$ for two hrs in a hot air oven. The aflatoxin was extracted and quantified.

The percentage difference in the toxin content between the beginning and end of the trials in the highgrade bentonite treated and control flask was calculated. Percent adsorption of the aflatoxin in different treatments was determined by subtracting the percent difference in aflatoxin content in the control flasks from that of the treated flasks in the respective treatment.

Percentage adsorption $=$

$$
\frac{\left(\mathrm{B}_{\mathrm{T}}-\mathrm{E}_{\mathrm{T}}\right)}{\mathrm{B}_{\mathrm{T}}}-\frac{\left(\mathrm{B}_{\mathrm{C}}-\mathrm{E}_{\mathrm{C}}\right)}{\mathrm{B}_{\mathrm{C}}}
$$

Where $\quad \mathrm{BT}=$ Toxin content in the treated flasks at the beginning

$\mathrm{BC}=$ Toxin content in the control flasks at the beginning

$\mathrm{ET}=$ Toxin content in the treated flask at the end

$\mathrm{EC}=$ Toxin content in the treated flask at the beginning

2.4 Statistical analysis: The results were subjected to one-way analysis of variance. Means were compared using Tukey method described by Snedecor and Cochran [10]. The level of significance was tested $\mathrm{P}<0.05$.

\section{RESULTS AND DISCUSSION}

The results on testing of per cent binding ability (adsorption) of aflatoxin B1 (AF) by graded levels of high grade bentonite (HGB) at $\mathrm{pH} 4.5$ and $\mathrm{pH} 6.5$ are presented in Tables 1 and 2, respectively. Significant differences $(\mathrm{P}<0.05)$ were noted among the different dietary treatments for percentage binding of AF by graded levels of high grade bentonite (HGB) at $\mathrm{pH} 4.5$ and 6.5.

At $\mathrm{pH}$ 4.5, highest binding percentage of $\mathrm{AF}(92.90 \%)$ was recorded with diet containing 1.0 per cent high grade bentonite, followed by 0.75 per cent high grade bentonite $(88.47 \%)$ and 0.50 per cent high grade bentonite $(84.90 \%)$ groups. Statistically significant differences $(\mathrm{P}<0.05)$ were noted in binding ability of AF among 1.0 per cent high grade bentonite (HGB) and other two levels. However, the difference between the 0.75 and 0.50 per cent levels was statistically non-significant. Though the exact mechanism of action of high grade bentonite (HGB) to adsorb AF in vitro is not yet elucidated, it is expected that AFB1 absorbed on to edge of montomorillonites by a double hydrogen bond and AFB1 molecule did not penetrate into the interlayer area of montomorillonites [11]. However, the ability of bentonite to bind mycotoxins depends on $\mathrm{pH}$, molecular arrangement and its geographic region of origin [7].

At $\mathrm{pH}$ 6.5, highest binding percentage of $\mathrm{AF}$ was noted with the diet containing 1.0 per cent high grade bentonite (96.80\%), followed by 0.75 per cent $(91.47 \%)$ and 0.5 per cent group (87.60\%). Significant difference $(\mathrm{P}<0.05)$ was noted in binding percentage of AF between 1.0 percent high grade bentonite (HGB) and other two levels, but the difference between the 0.75 and 0.50 per cent levels were statistically non-significant. Similar results have been reported by several workers. [12,13,14,15,16,17].

From the results of in vitro studies, it is concluded that a high grade bentonite (HGB) had a high ability to adsorb AF from the feed. The highest binding percentage was recorded for 1.0 per cent $(92.90 \%, 96.80 \%)$ followed by 0.75 per cent $(88.47 \%, 91.47 \%)$ and 0.5 per cent $(84.90 \%, 87.60 \%)$, HGB at pH 4.5 and 6.5 , respectively.

\section{References}

[1] Manafi, M., Narayana Swamy, H. D. and Pirany, N. 2009a. In vitro Binding Ability of Mycotoxin Binder in Commercial Broiler Feed. African J. Agr. Res., 4(2):141-143.

[2] Mohamadi, H. and Alizadeh, M. 2010. A Study of the Occurrence of Aflatoxin M1 in Dairy Products Marketed in Urimia, Iran. $J$. Agr. Sci. Tech., 12: 579-583

[3] Devegowda, G., 2002. Mycotoxins: Economic risks and their control. In: Handbook of Poultry Nutrition. Published by American Soybean Association, pp. 246-260.

[4] Eralsan, G., Essz, D., Akdogan, M., Sahindokuyucu, F. and Altrintas, L. 2005. The effects of Aflatoxin and Sodium Bentonite and Alone on Some Blood Electrolyte Levels in Broiler Chickens. Turk Vet. Hayvanclk Dergisi., 29: 601- 605.

[5] Hagler, W. M., Tyczkowska, K. and Hamilton, P. B. 1984. Simultaneous Occurrence of Deoxynivalenol, Zearalenone and Aflatoxin in 1982 Scabby Wheat from Midwestern United States. Appl. Environ.Microbiol., 47: 151-154.

[6] Santurio, J. M., Mallmannl, C. A., Rosa, A. P., Appel, G., Heer, A., Dageforde, S. and Bottcher, M. 1999. Effect of Sodium Bentonite on the Performance and Blood Variables of Broiler Chickens Intoxicated with Aflatoxin. Brit. Poultry Sci., 40: 115- 119. 
[7] Vieira, S.L. 2003. Nutritional implication of mould development in feed stuffs and alternatives to reduce the mycotoxin problem in poultry feeds. World's Poultry Science Journal, Vol.59. March 2003. pp.111-122.

[8] Shotwell, O.L., Hesseltine, C.W., Stubblefield,R.D. and Sorenson,W.G.,1966.Production of aflatoxin on rice. Appl.Micrbial.,14:425-428

[9] Romer, T.R., 1975, Screening method for the detection of aflatoxins in mixed feeds and other agricultural commodities with subsequent confirmation and quantitative measurement of aflatoxins in positive samples. J.A.O.A.C., 58: $500-506$.

[10] AOAC, 1995. Official Methods of Analysis. $16^{\text {th }}$ Ed., Association of Official Analytical Chemists, Washington, D.C.

[11] Snedecor, G.W. and W.G.Cochran, 1989. Statistical methods. Sixth ed. Iowa State University Press. Ames. Owa.

[12] Desheng, Q., Fan,L., Yanhu, Y. and Niya, Z. 2005. Adsorption of aflatoxin B $_{1}$ on montmorillonite. Poultry Science. 84(6): 959-961

[13] Raju, M. V. L. N. and Devegowda, G. 2002. Esterifed Glucomannan in Broiler Chicken Diets Contaminated with Aflatoxin, Ochratoxin and T-2

Toxin: Evaluation of Its Binding Ability (In vitro) and Efficacy as Immunomodulator. Asian-Aust. J. Anim. Sci., 15: 1051-1056.

[14] Arvind, K. L., Patil, V. S., Devegowda, G., Umakantha, B. and Ganpule, S. P. 2003. Efficacy of Esterified Glucomannan to Counteract Mycotoxicosis in Naturally Contaminated Feed on Performance, Serum Biochemical and Hematological Parameters in Broilers. Poultry Sci., 82: 571-576.

[15] Perozo, F. and Rivera, S. 2003. Effect of Aflatoxin B1 Exposure and Selenium Supplementation on Immune Response in Broilers. Indian Vet. J.80: 1218-1221.

[16] Girish, C. K. and Devegowda, G. 2004. Evaluation of Modifies Glucomannan (Mycosorb) and HSCAS to Ameliorate the Individual and Combined Toxicity of Aflatoxin and T-2 Toxin in Broiler Chickens. Aust. Poult. Sci. Symp., 16: 126-129.

[17] Miazzo, R., Pevalta, M. F., Magnoli, C., Salvano, M., Ferrero, S., Chiacchiera, S. M., Carralno, E. C. Q., Rosa, C. A. R. and Dalcero, A. 2005. Efficacy of Sodium Bentonite as a Detoxifier of Broiler Fed Contaminated with Aflatoxin and Fumonisin. Poultry Sci., 84: 1-8.

Table 1. Per cent binding of aflatoxin (AF) by varying levels of high grade bentonite (HGB) in different treatments in vitro at ${ }_{\mathrm{p}} \mathrm{H} 4.5$ (Mean $\pm \mathrm{SE}$ ).

\begin{tabular}{|c|c|c|c|c|}
\hline \multicolumn{4}{|c|}{ Treatments } & \multirow{3}{*}{$\begin{array}{l}\text { Binding Percentage } \\
00.00 \pm 0.00^{\mathrm{c}}\end{array}$} \\
\hline AF (ppm) & & $\overline{\text { GB }\left({ }^{c}\right.}$ & & \\
\hline 0.5 & - & - & - & \\
\hline 0.5 & 0.5 & - & - & $87.60 \pm 0.4041^{\mathrm{b}}$ \\
\hline 0.5 & - & 0.75 & - & $91.47 \pm 1.184^{b}$ \\
\hline 0.5 & - & - & 1.0 & $96.80 \pm 1.212^{\mathrm{a}}$ \\
\hline
\end{tabular}

Means within each column bearing common superscript do not differ significantly $(\mathrm{P}<0.05)$

Table 2. Per cent binding of aflatoxin (AF) by varying levels of high grade bentonite (HGB) in different treatments in vitro at ${ }_{\mathrm{p}} \mathrm{H} 6.5$ (Mean $\left.\pm \mathrm{SE}\right)$.

\begin{tabular}{|c|c|c|c|c|}
\hline \multicolumn{4}{|c|}{ Treatments } & \multirow{3}{*}{$\begin{array}{l}\text { Binding Percentage } \\
00.00 \pm 0.00^{\mathrm{c}}\end{array}$} \\
\hline AF (ppm) & \multicolumn{3}{|c|}{ HGB (\%) } & \\
\hline 0.5 & - & - & - & \\
\hline 0.5 & 0.5 & - & - & $84.90 \pm 0.8145^{b}$ \\
\hline 0.5 & - & 0.75 & - & $88.47 \pm 1.09^{b}$ \\
\hline 0.5 & - & - & 1.0 & $92.90 \pm 1.266^{\mathrm{a}}$ \\
\hline
\end{tabular}

Means within each column bearing common superscript do not differ significantly $(\mathrm{P}<0.05)$ 